\title{
A Commognitive Framework: The Process of Solving Mathematical Problems of Middle School Students
}

\author{
Moh. Zayyadi \\ University of Madura, Indonesia \\ Toto Nusantara, Subanji, Erry Hidayanto, I Made Sulandra \\ State University of Malang, Indonesia
}

\begin{abstract}
This study aims to describe students' ability to solve mathematical problems from a commognitive point of view, It will describe their word use, visual mediators, narratives, and routines. This type of research is qualitative research with a descriptive approach. The research method is comprised of four steps: (1) preparation, (2) collecting data, (3) transcribing the data, and (4) analyzing the data. The results of the study showed that the subject manifested visual markers of algebraic expressions in verbal terms and used words symbolically. The subject used sketching as a visual mediator, and the sketch was divided into parts. Narrative was used by students in relation to broad rectangular theorems and the concepts of addition, subtraction, and multiplication. The subject carried out a routine to solve the problem, which consisted of writing down what was known, dividing the problem into several parts, identifying the purpose of the problem, and making a sketch to determine how much fabric remained unused.
\end{abstract}

Keywords: Commognitive, Problem Solving, Visual Mediator, Word Use, Routines, Narrative.

\section{Introduction}

The process of solving problems is part of the commognitive process of individualisation carried out by each student. Despite being an internal process, it still involves communication. The processes of individualisation and communication are reflexively interrelated (Sfard, 2007). 'Commognitive' is a combination of the words 'communication' and 'cognitive'. Commognitive methodologyes analyse how students solve mathematical problems (Presmeg, 2016). The purpose of commognitive analysis is to observe students' ability to solve problems not only by the results they obtain but also by the words used, routines performed, and visual narratives and mediators used to solve the problem. 
Problem solving is at the core of mathematics learning (Subanji, 2013), and there is a strong relationship between students' beliefs and problem-solving behaviour and their academic performance (Callejo \& Vila, 2009). In Indonesia's 2013 curriculum, mathematical problem solving became one of the competencies that middle school students must demonstrate. Some theorists argue that there are various components to the problem-solving process (Bransford \& Stein, 1993; Gick, 1986; Pugalee, 2004; Bransford, Sherwood, Vye, \& Rieser, 1986; Polya, 1954), but for the purpose of this study the researchers will emphasise five components: identify, define, explore, act, and search. This is also known as the IDEAL approach to problem solving (Bransford \& Stein, 1993). The stages of IDEAL problem solving are shown in table 1.

Problem solving in mathematics learning can be interpreted as the series of processes followed to solve problems (Blum \& Niss, 1991) or the direct goals of a series of commognitive processes (Jonassen, 2000). Problem solving can also be used to develop students' commognitive abilities (Jonassen, 2000), encourage creativity (Bransford \& Stein 1993), and develop oral and written abilities that are part of the mathematical application process (Pugalee, 2004). It can also increase students' motivation to learn mathematics (Song \& Grabowski, 2006).

Therefore, problem solving is one of the main goals of learning mathematics.

Several problem-solving models have been proposed so far, one of which consists of three stages: constructing the representation of problems, finding solutions, and implementing existing solutions (Gick, 1986). Another widely used problem-solving model consists of four stages, namely understanding problems, planning solutions, resolving problems according to the plan, and checking again on all steps that have been taken (Polya, 1954). The scientific method is comprised of six stages (Kennedy, Tipps, \& Johnson, 2008): (1) understand the problem; (2) make a plan; (3) arrange experiments or observations; (4) collect and analyse data; (5) determine conclusions; and (6) interpret and evaluate solutions.

Table 1: The Stages of IDEAL Problem Solving

\begin{tabular}{ll}
\hline IDEAL Stages & \multicolumn{1}{c}{ Description } \\
\hline $\begin{array}{l}\text { Identification of } \\
\text { problems }\end{array}$ & $\begin{array}{l}\text { Understand the problems in general and break them into several } \\
\text { parts. }\end{array}$ \\
\hline Define goals & Set goals to be achieved. \\
\hline $\begin{array}{l}\text { Explore possibe } \\
\text { strategies }\end{array}$ & $\begin{array}{l}\text { Look for various alternative solutions to problems and conduct } \\
\text { studies on each alternative from different perspectives. }\end{array}$ \\
\hline $\begin{array}{l}\text { Anticipate } \\
\text { outcomes }\end{array}$ & $\begin{array}{l}\text { Choose one solution and solve the problem according to the } \\
\text { chosen strategy. }\end{array}$ \\
\hline Look back & $\begin{array}{l}\text { See the match between the goals to be achieved and the results } \\
\text { obtained and learn from the strategies used in solving the } \\
\text { problem. }\end{array}$ \\
\hline
\end{tabular}

Commognitive is a new word formed by combining 'communication' and 'cognition' (Sfard, 2008). Sfard suggests that thinking is a form of 
communication and defines thinking as an individualised version of communication (Sfard \& Kieran, 2001; Sfard, 2007; 2008; 2012). Thinking is usually done internally and is generally considered to be inaccessible to others. Thought activity carried out individually seems to originate within a person and to take place biologically, but it still constitutes a form of communication from the individual to himself (Sfard, 2001; 2008; 2012). Although thinking is individual, the thought requires support from outside and does not have to be personal or to have vocal or visual elements or words (Sfard, 2007; 2008; Sfard \& Kieren, 2001).

Sfard defines communication as an activity that causes one individual's actions to be followed by action from other individuals. The first individual's action must be well defined as an act of communication, and the second individual's action must be a reaction to previous actions (Sfard, 2008). For communication to be effective, it is important to ascertain the similarity of the message received from an idea, meaning, or feeling to the message the sender intended (Sfard, 2001). Basically, communication is not only the exchange of messages in the context of asocial process, but it also depends on the socio-cultural context, including even visual means of sending messages such as gestures, pointers, stances, and the like (Sáenz-Ludlow \& Kadunz, 2016). Therefore, non-verbal communication cannot be separated from the message in the study of communication.

Communication varies according to the object or mediator used to provide the rules followed by the interlocutor. The combination of all types of communication carried out by several individuals is called 'discourse' (Sfard, 2008). Discourse is the communication of ideas, information, etc., especially speech or conversation (Neufeldt \& Guralnik, 1988). Discourse as a specific example of communication, whether diachronic or synchronic, whether with other people or with oneself, takes place pre dominantly verbally or with the help of other symbolic systems (Sfard, 2001; 2007). Discourse can occur when someone is given a problem and tries to solve it. This happens because in trying to solve mathematical problems, the person's discourse skills change to a new communication format. The components examined as part of the commognitive analysis in this study were word use, visual mediators, supported narratives, and routines.

Word use: The word sused in mathematical discourse must be mathematical, such as words for numerals, geometric concepts, quantities, and shapes. Word use is important because it provides clues about how users perceive the world (Sfard \& Lavie, 2005; Sfard, 2007; 2008), and it includes the use of mathematical terminology such as 'topology' as well as ordinary words with specific meanings in mathematics such as 'boundaries', 'open', 'continuous', and 'group' (Nardi et al., 2014). Mathematical discourse of functions for example, includes words such as 'domains', 'ranges', 'values', 'definitions', and the like (Viirman, 2015). In this study, words including algebraic, numerical, geographical, and equation-related terms used by students in solving mathematical problems were examined. 
Visual mediator: Visual mediators are objects that are manipulated as part of the discourse process (Viirman, 2015) or objects used to describe other objects in discourse (Thoma \& Nardi, 2016). Examples of objects used in mathematical discourse include diagrams, symbols, and graphics as well as physical objects used as props in teaching mathematics (Nardi et al., 2014). Numbers, algebraic formulas, algebraic notations, graphs, drawings, and diagrams are the most widely used examples of visual mediators in mathematics (Sfard, 2007; 2008). In this study, visual mediators are considered to be objects such as graphics, images, diagrams, and others that are used by students in solving mathematical problems.

Narrative: The intended narrative is a sequence of speech, oral or written, framed as a description of the relations between objects or of activities with or by objects (Thoma and Nardi, 2016; Virmaan, 2015; Nardi et al, 2014). Mathematical theories, definitions, proofs, and theorems are narratives of mathematical discourse (Sfard, 2007; 2008). In particular, in research, supported narratives are considered to be narratives that become mathematical facts, such as axioms, definitions, and theorems, used by students in solving mathematical problems.

Routine: A routine is a metarule process that describes patterns in discouraging activities (Thoma and Nardi, 2016). A routine is a repetitive pattern of elements in discourse such as defining, estimating, proving, estimating, predicting, and abstracting (Nardi et al, 2014). Calculations are one example of a type of routine that produces narratives about the number of objects in a particular situation. In this research, a routine is defined as a process carried out by students such as defining, estimating, or proving in the course of solving the problems provided. Many studies on problem solving have described the problems associated with gaining students' trust (Kloosterman \& Stage, 1992; Callejo \& Vila, 2009; Bal, 2015) and encouraging them to solve problems with a metacognitive approach (Schoenfeld, 1992; Naufal, Atan, Abdullah, \& Abu, 2017) and mathematical thinking (Henningsen \& Stein, 1997; Sangpom, Suthisung, Kongthip, \& Inprasitha, 2016). In addition, commognitive research is still much more focused on teachers than on learners (Berger, 2013; Nardi, Ryve, Stadler, \& Viirman, 2014; Viirman, 2015; Tabach \& Nachlieli, 2016; Metzuyanim \& Tabach, 2017; Tasara, 2017). Commognitive research related to problem solving has never been done by other researchers. Therefore, it is necessary to do a study on problem solving from a commognitive perspective. In this study, the researchers aimed to describe students' ability from a commognitive perspective as they solved mathematical problems.

\section{Method}

This study aims to describe students' ability to solve mathematical problems from a commognitive point of view. This type of research is qualitative, with a descriptive approach. Four important steps were: (1) preparation, (2) collecting data, (3) transcripts of data, and (4) analyzing data. 


\subsection{Prepation}

At the preparation stage, the researchers developed the test and interview instruments that enabled the participants to be involved in the process of solving mathematical problems. The test instrument involved mathematical questions on Figure 1, that give participants the opportunity to demonstrate the use of commognitive components (word use, visual mediators, routines, and narratives) in solving mathematical problems in Table 2. Furthermore, the interviews were designed to articulate students' thought processes as they solved mathematical problems.

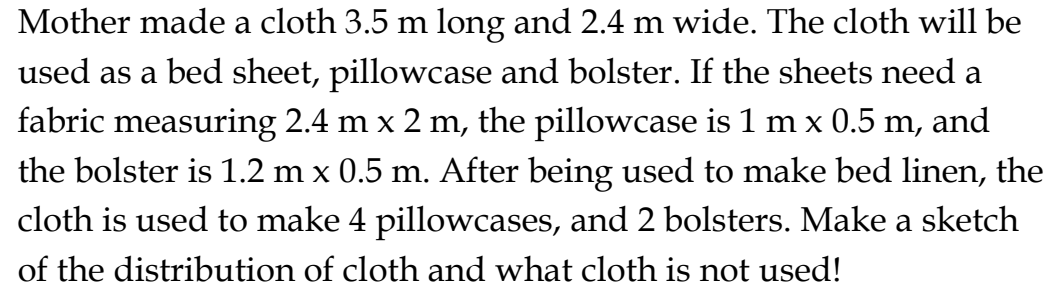

Table 2: Indicators of the Commognitive Components Used in Solving Mathematical Problems

\begin{tabular}{ll}
\hline Commognitive Component & \multicolumn{1}{c}{ Indicator } \\
\hline Word use & $\begin{array}{l}\text { Writes and recites words including algebraic, numerical, } \\
\text { and geomantic terms, equations, and other terms used by } \\
\text { students in solving mathematical problems }\end{array}$ \\
\hline Visual mediator & $\begin{array}{l}\text { Uses objects such as graphics, images, diagrams, and } \\
\text { others in solving mathematical problems }\end{array}$ \\
\hline Narrative & $\begin{array}{l}\text { Describes mathematical facts such as axioms, definitions, } \\
\text { and theorems that are used by students in solving } \\
\text { mathematical problems }\end{array}$ \\
\hline Routines & Explains the steps followed to solve the problems given \\
\hline
\end{tabular}

\subsection{Participants and Collecting data}

The study was conducted in State Junior High School 1 Pamekasan with VIID class research subjects. The VIID class is chosen because it is a superior class and consists of 35 students. The students about the age of 13 years. The process of data collection began with providing mathematical problems based on problem solving to 35 students for individual completion. Ten students who answered the questions given. These 10 students were the subjects in this study. Of the 10 subjects in table 3, 5 answered correctly without using problem solving, 3 answered with problem solving but gave in correct final answers, and 2 answered with problem solving and correct answers. After that, the researchers conducted a data analysis of the answers provided by the subjects based on the stages of problem solving and the components of the commognitive.

\subsection{Analyzing data}

In the process of implementing the settlement, students are asked to voice their thoughts aloud. Students are given the opportunity to explore, take notes, and 
say all their thoughts and ideas. The researchers observes and records all behaviours including students' verbalized thoughts during the work done by students. After the students completed the work, the researchers transcribed the data, and the students who were the research subjects were interviewed individually to explain their problem-solving process from a commognitive point of view. The researchers then conducted a data reduction by removing the elements that were considered insignificant from all the data (observations, interviews, thinking aloud, and field notes) to be examined in the data analysis process.

\section{Result and Discussion}

In this study, students were given problems about algebra and were required to answer by writing all the steps they followed in detail along with their reasoning. Based on the data obtained, there are several differences in the strategies used by students to solve problems. Some students experimented, while others made images or found and used patterns. These three types of strategies included several steps of IDEAL problem solving. Based on the data collected, there were 10 research subjects in table 3, consisting of 5 students who answered correctly without using problem solving, 3 who gave an incorrect answer but used problem solving strategies, and 2 who answered correctly and used problem solving strategies. After that, the researchers analysed the data by looking at the tendency of the answers made by the subject based on the stages of problem solving used and the components of the commognitive.

Table 3: Research subjects

\begin{tabular}{|l|l|}
\hline Using problem solving & $\begin{array}{l}\text { Without using problem } \\
\text { solving }\left(^{*}\right)\end{array}$ \\
\hline $\begin{array}{l}5 \text { students inclue (3 who gave an incorrect } \\
\text { answer but used problem solving strategies } \\
\text { and } 2 \text { who answered correctly and used } \\
\text { problem solving strategies) }\end{array}$ & 5 students \\
\hline
\end{tabular}

\subsection{Subject without using problem solving}

One of the 5 subjects $\left(^{*}\right)$ who answered the problem correctly but did not use problem solving immediately began working without writing down what was known and what the purpose of the problem was. For an example of an answer from this subject in Figure 2.
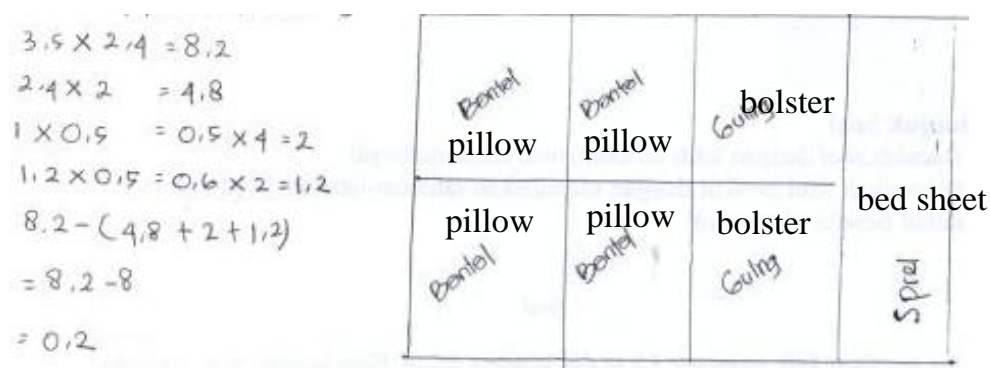

Figure 2. Example one answer from 5 subjects 
Based on the data above, 5 subjects did not use the stages of problem solving in finding a solution. The first subject worked directly on the problem. In this case, the strategy used is to try to apply existing mathematical knowledge gained from exploring past mathematical situations (Nunokawa, 2005) instead of writing down what is known and the goal of the problem. The subject did not explore strategies that might have provided a solution and did not carry out the process of checking again. In this case, the only commognitive components of the answers provided by students were word use, namely writing an answer such as ' $3.5 \times 2.4=8.2,2.4 \times 2.4=4.8$ ', and the use of a visual mediator, specifically drawing a sketch (Posamentier \& Krulik, 2009).

\subsection{Subject using problem solving}

In addition to the types of answers written by the 5 subjects above, there were 5 subjects who provided answers using problem solving. Of these, 2 students answered correctly in Figure 5a and 3 students answered incorrectly in Figure $5 b$.

At the stage of problem identification, the subject understood the problem in general and broke it down into several parts such as the size of the overall fabric, the size of the bed sheet, the size of the bolster, and the size of the pillowcase. Dividing the problem into several parts made it easier for the subject to understand the problem. The information known from the existing problem is recorded in Figure 3.

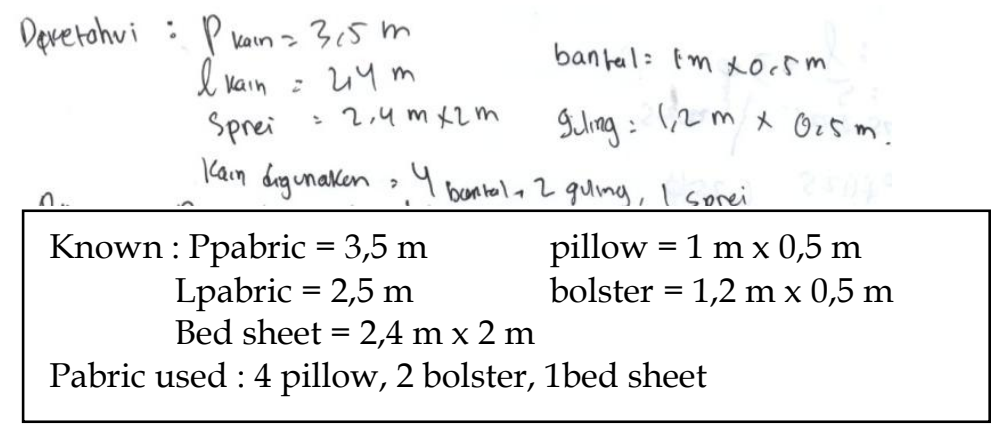

Figure 3. Stages of students' understanding

The subject used mathematical words by writing and saying aloud that the size of the cloth was $\mathrm{p}=3.5 \mathrm{~m}$ and $\mathrm{l}=2.4 \mathrm{~m}, 2.4 \mathrm{~m}$ and $2 \mathrm{~m}$ on the bed sheet area, 1.2 $\mathrm{m}$ and $0.5 \mathrm{~m}$ in bolsters, and $1 \mathrm{~m}$ and 0.5 on pillowcases. This is in accordance with Nardi et, al (2014), who explained that visual markers of algebraic expressions are often manifested in verbal terms. In addition, the student used visual mediators to dividing the cloth into several parts by sketching, as shown in Figure 4.

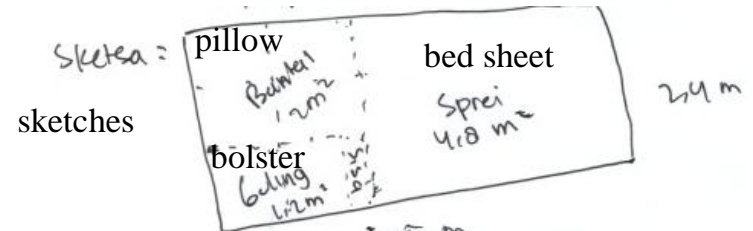

Figure 4. Sketcheš madê by the subject 
At the stage of developing data to determine goals, the subject drew sketches in order to more easily identify the objectives of the problem. The subject then explained that the purpose of this problem was to look for the remaining unused fabric. By sketching fabric for several sizes of bed sheets, pillowcases, and bolsters, it was possible to measure the fabric that was not being used in Figure 4. The subject also wrote some numbers, such as $3.5 \mathrm{~m}, 2.4 \mathrm{~m}$, etc. on the sketch. It is appropriate that words and visual mediators serve as a medium for making meaning (Kim, Choi, \& Lim, 2017).

At the stage of exploring possible strategies, the subject uses a two-step strategy by sketching first and then determining the size of the rest of the fabric by reducing the area of the cloth as a whole by the area of cloth used for the bed sheet, pillowcase, and bolster. The narrative component connected the sketches with the strategies that might be used to find the area of the remaining fabric. Students often try out possible strategies that could be used to find solutions at this stage, although in this case the subject only used one strategy to solve the problem.

At the stage of implementing the strategy, the subject implemented a strategy that had been explored at a previous stage by sketching it first and determining the rest of the fabric by reducing the area of the cloth as a whole with the area of cloth used (bed sheet, pillowcase and bolster). As shown in Figure 5, the subject made a sketch showing the parts of the fabric used for the bed sheets, pillow covers, and bolsters, and the cloth that was not used. The subject determined the amount of unused fabric by looking for the area of the fabric of $8.4 \mathrm{~m} 2$ with $\mathrm{p}=$ $3.5 \mathrm{~m}$ and $\mathrm{l}=2.4 \mathrm{~m}$, and then the subject found the area of the sheet with $\mathrm{p}=2.4$ $\mathrm{m}$ and $\mathrm{l}=2 \mathrm{~m}$, namely $4.8 \mathrm{~m} 2$. The subject then found the area of the pillowcase by multiplying $p=1 \mathrm{~m}$ and $1=0.5 \mathrm{~m}$, giving an area of $0.5 \mathrm{~m} 2$, and the area of the pillow case by multiplying $\mathrm{p}=1.2 \mathrm{~m}$ and $1=0.5 \mathrm{~m}$ for an area of $0.6 \mathrm{~m} 2$. The subject then added the area of 4 pillowcases and 2 bolsters on the grounds that the area of the pillowcase and bolster were already known, so it was possible to calculate that the size of 4 pillowcases would be $2 \mathrm{~m} 2(0.5 \mathrm{~m} \times 4 \mathrm{~m})$ and the size of 2 sarongs bolsters would be $1.2 \mathrm{~m} 2(0.6 \mathrm{~m} \times 2 \mathrm{~m})$. Then, the subject added 4 pillowcases and 2 bolsters to the area of the sheet to reach $8 \mathrm{~m} 2$. In determining the remaining unused fabric, the subject reduced the area of available fabric by the total area of fabric used, namely $8.4 \mathrm{~m} 2-8.0 \mathrm{~m} 2$ so that the area of the unused fabric was $0.4 \mathrm{~m} 2$. In this case, the subject got the amount from the 0.4 $\mathrm{m} 2$ of leftover cloth in Figure 5a. What distinguishes the two types of subjects that answered the problem using the stages of problem solving is the implementation of the strategy that they used. The first difference was that the subjects whose final answers were incorrect added four pillowcases to2 pillowcases and listed the width of the fabric as 6.2 (circled in red in Figure 5b). In addition, another thing that becomes the second difference of the two types of subjects that use the stages of the problem is the subject that does not answer the final result correctly, namely the broad theorem of the rectangle, should the unit used be $\mathrm{m} 2$ not just $\mathrm{m}$ (blue circle). These two differences distinguish two types of subjects who answer using the stages of problem solving. 


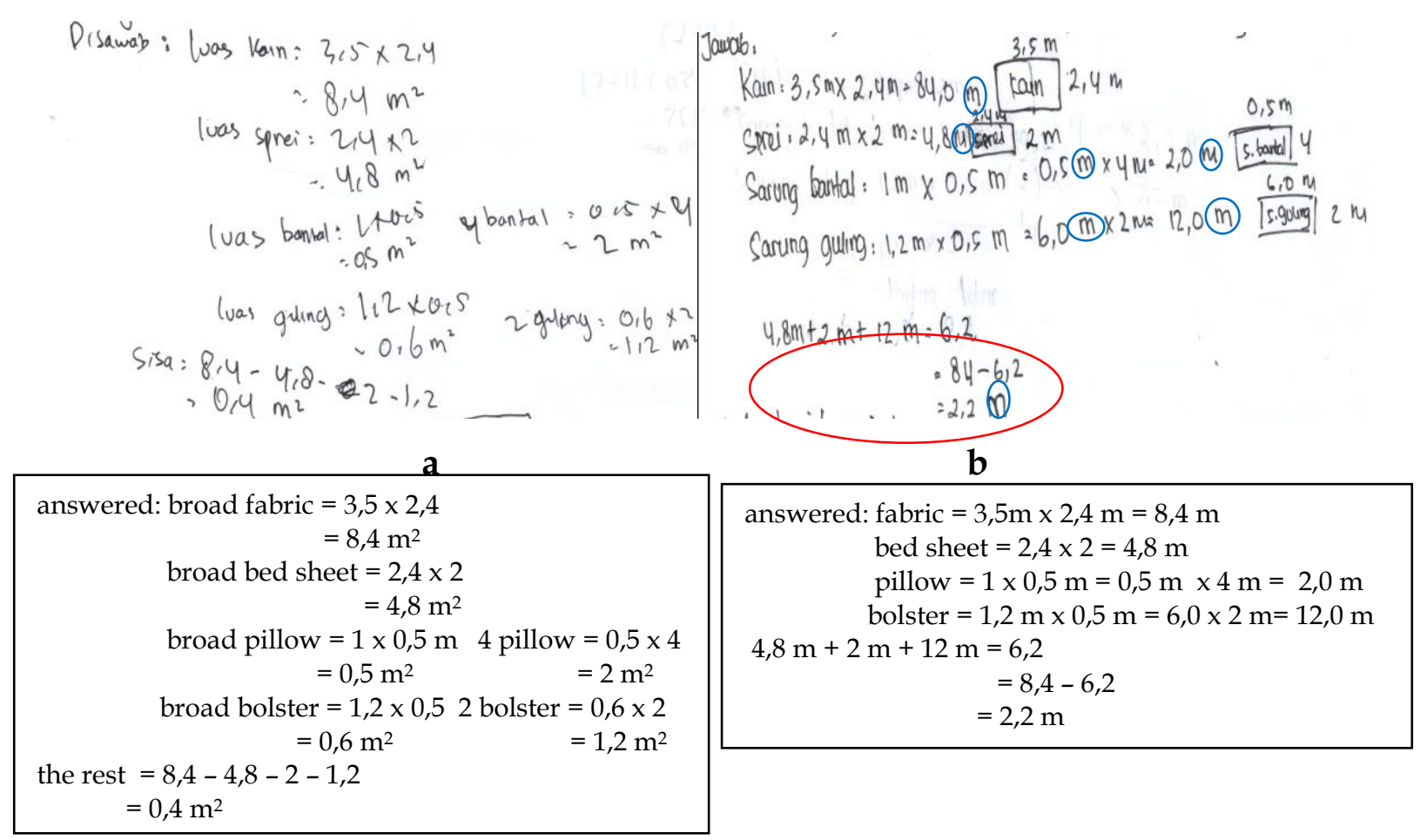

Figure 5. The subject carries out the strategy

At this stage the subject used mathematical language to write and say the steps of the strategy used to find the solution, for example in the following conversation:

Researchers: How do you solve this problem?

Subject: I sketched the pack, dividing the sheets, pillow cases, rolling gloves.

Researchers: Why are you sketching?

Subject: With sketches, I am easier to answer problems.

Researchers: Why is the sketch like that?

Subject: I made it that way, with a sketch that can determine the rest of the cloth, sir.

Researchers: After sketching, what else do you do?

Subject: I am looking for a cloth area, sir

$$
\begin{aligned}
& \text { was kain: } 3,5 \times 2,4 \\
& \therefore 8,4 \mathrm{~m}^{2} \\
& \text { luas sprei: } 2,4 \times 2 \\
& -4,8 \mathrm{~m}^{2} \\
& \text { luas bental: } \begin{aligned}
\text { LNois } \\
=0,5 \mathrm{~m}^{2}
\end{aligned} \\
& \text { (vas guing: } \begin{aligned}
& 1,2 \times 0,5 \\
& =0,6 \mathrm{~m}^{2}
\end{aligned}
\end{aligned}
$$

$$
\begin{aligned}
& \text { broad fabric }=3,5 \times 2,4 \\
& =8,4 \mathrm{~m}^{2} \\
& \begin{aligned}
\text { broad bed sheet }=2,4 \times 2 \\
=4,8 \mathrm{~m}^{2}
\end{aligned} \\
& \begin{aligned}
\text { broad pillow }= & 1 \times 0,5 \mathrm{~m} \\
= & 0,5 \mathrm{~m}^{2} \\
\text { broad bolster } & =1,2 \times 0,5 \\
= & 0,6 \mathrm{~m}^{2}
\end{aligned}
\end{aligned}
$$

Researchers: What do you do for that, sister?

Subject: By knowing the area of the fabric, the size of the bed sheet, the area of the pillowcase, and the width of the pillow case, I could look for the rest of the cloth, sir.

Researchers; How? Basically, what's the broad concept?

Subject: What do you mean, sir?

Researchers: Try to pay attention to the width of the cloth you are working on. 
Subject: I don't understand sir; oooh sir, it's supposed to be $8.4 \mathrm{~m}^{2} \mathrm{sir}$.

Researchers: Sister understand the theorem?

Subject; No,sir.

Researchers: Continue the work that was previously

Subject: After getting 1 pillowcase and 1 bolster, I multiply 4 for the pillowcase and 2 for the bolster.

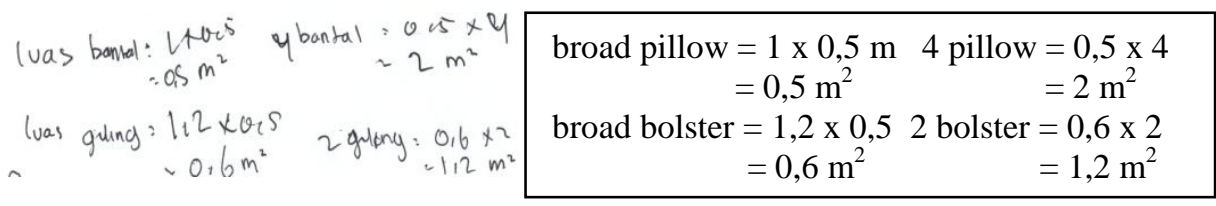

Researchers: How much for 4 pillowcases and 2 bolsters?

Subject: $32 \mathrm{~m}$ sir.

Researchers: $32 \mathrm{~m}$ ?

Subject: Hehehe, $3.2 \mathrm{~m}^{2}$ sir.

Researchers: Continue.

Subject: Yes, just add the sheet area to3.2 $\mathrm{m}^{2}$.

Researchers; What for?

Subject: For the rest of the cloth pack, like sir ...

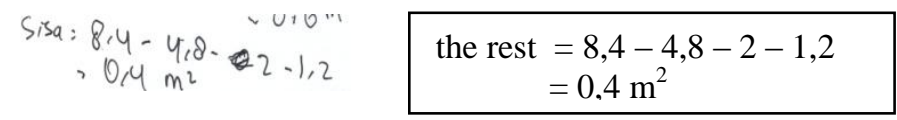

Subject: So the rest is $0,4 \mathrm{~m}$ sir

During these conversations, the subject used sketches as visual mediators at the initial stages of implementing strategies for problem solving. Students use narratives to explain the broad theorem of rectangles (looking for the area of the cloth, bed sheets, and pillowcases), the concepts of addition (putting 4 pillowcases with 2 bolsters), subtraction (total fabric area minus total area used), and multiplication (4 bolsters and 2 pillowcases), although students do not fully understand the broad rectangular theorem. This is supported by the fact that they continued to write units of area using ' $\mathrm{m}$ ' instead of ' $\mathrm{m} 2$ '. These results indicate that the subject only used his mind without using supported narratives in solving problems. The research findings are consistent with the claims of Hoch and Dreyfus (2004) that there is no correlation between student structure and manipulation skills. In addition, it supports the view that students who do not have so-called mind structures cannot use properties of numbers or functions to solve linear equations, but depend on other people's routines (Linchevski \& Livneh, 1999 and Hoch \& Dreyfus, 2004).

The subject carried out a routine in solving the problem by explaining the steps in full, writing down what was known, dividing the problem into several parts (cloth, bed sheet, and pillowcase), identifying the goal of the problem, and making a sketch to determine the amount of unused fabric. Routines carried out by a subject can be flexible and do not always follow the externally provided steps exactly. This is in line with the research conducted by Sfard \& Lavie (2005) that categorised routines into types, namely ritual and exploration. Ritual routines are characterized by rigid rule-following where truth is determined by 
external authorities. Exploration routines, on the other hand, are flexible, often dealing with mathematical objects and justified by mathematical means.

At the stage of checking again, the subject checked on what had been done before but did not write down the final conclusion of the problem-solving process. This is consistent with the research conducted by Pugalee (2004), which states that the majority of students do not verify their final answer. The commognitive component did not appear at this stage because the subject did not write down the final conclusions of the problem-solving process.

\section{Conclusion}

This study has revealed students' ability to solve mathematical problems from a commognitive point of view. The analytical framework of commognitive theory (Sfard, 2008) can facilitate detailed analysis of the mathematical problemsolving processes of junior high school students. The results of the study showed that students used mathematical words in solving the problem by writing and discussing the size of the fabric, the size of the sheets, the width of the pillowcase, and the area of the pillowcase. Subjects mentioned visual markers of algebraic expressions in verbal terms, and used words symbolically. The students used sketches as visual mediators and divided the sketches into parts. The subject also used a sketch to more easily solve the problem and to explain the strategies he used. Students used narratives to explain the broad theorem of rectangles (looking for the area of the cloth, bed sheets, and pillowcases), the concepts of addition (adding 4 pillowcases to 2 bolsters), subtraction (total fabric area minus total area used), and multiplication ( 4 bolsters and 2 pillowcases), although students did not fully understand the broad rectangular theorem. This is supported by the fact that they continued to write units of area using ' $m$ ' instead of ' $\mathrm{m} 2$ '. These results indicate that the subject only used his mind without using supported narratives in solving problems. The subject carried out a routine in solving the problem by explaining the steps in full, writing down what was known, dividing the problem into several parts (cloth, bed sheet, and pillowcase), identifying the goal of the problem, and making a sketch to determine the amount of unused fabric.

The findings of this study indicate that students are still more focused on the final results than in the IDEAL problem solving process and many students do not look back at the IDEAL stage in doing their work. From a commognitive framework, the subjects tend to use mathematical words and visual mediators at the stage of understanding the problem, and narrative and routine at the stages of exploring and implementing strategies. Thus, this study provides an initial insight into how students describe mathematical problems from a commognitive perspective.

With this study, the researchers hope that commognitive theory can provide a theoretical and analytical perspective in understanding how students think about solving mathematical problems. The researchers suggest further research investigating how teachers and materials such as textbooks influence students' thought processes from a commognitive perspective. 


\section{References}

Bal, A. P. (2015). Examination of the mathematical problem-solving beliefs and success levels of primary school teacher candidates through the variables of mathematical success and gender. Kuram ve Uygulamada Egitim Bilimleri, 15(5), 1373-1390. https:// doi.org/10.12738/estp.2015.5.2573

Berger, M. (2013). Examining mathematical discourse to understand in-service teachers' mathematical activities. Pythagoras. https://doi.org/10.4102/pythagoras.v34i1.197

Blum, W., \& Niss, M. (1991). Applied Mathematical Problem Solving, Modeling, Applications, and Links to Other Subjects: State, Trends and Issues in Mathematics Instruction. Educational Studies in Mathematics, 22(1), 37-68.

Bransford, J., Sherwood, R., Vye, N., \& Rieser, J. (1986). Teaching Thinking and Problem Solving. Research Foundations. American Psychologist, 41(10), 1078-1089. https:// doi.org/10.1037/0003-066X.41.10.1078

Bransford, J., \& Stein, B. (1993). The Ideal Problem Solver. Centers for Teaching and Technology - Book Library. https:/ / doi.org/10.1109/ISSNIP.2007.4496930

Callejo, M. L., \& Vila, A. (2009). Approach to mathematical problem solving and students' belief systems: Two case studies. Educational Studies in Mathematics, 72(1), 111-126. https:// doi.org/10.1007/s10649-009-9195-z

Gick, M. L. (1986). Problem-solving strategies. Educational Psychologist 21, 99-120. Retrieved from http://www.amazon.com/exec/obidos/redirect?tag=citeulike0720\&path=ASIN $/ 0387982191$

Henningsen, M., \& Stein, M. K. (1997). Mathematical Tasks and Student Cognition: Classroom-Based Factors That Support and Inhibit High-Level Mathematical Thinking and Reasoning. Journal for Research in Mathematics Education, 28(5), 524. https://doi.org/10.2307/749690

Hoch, M., \& Dreyfus, T. (2004). Structure Sense In High School Algebra: The Effect Of Brackets A student made a minor mistake in solving a problem in a matriculation exam and obtained the following equation. Proceedings of the 28th Conference of the International Group for the Psychology of Mathematics Education, 49-56. Retrieved from https://www.emis.de/proceedings/PME28/RR/RR025_Hoch.pdf

Jonassen, D. H. (2000). Toward a design theory of problem solving. Educational Technology Research and Development, 48(4), 63-85. https://doi.org/10.1007/BF02300500

Kennedy, L. M., Tipps, S., dan Johnson, A. (2008). Guiding Children's learning mathematics (11th ed.). Balmont: Thomson Wadsworth

Kim, D.-J., Choi, S., \& Lim, W. (2017). Sfard's Commognitive Framework as a Method of Discourse Analysis in Mathematics. International Scholarly and Scientific Research \& Innovation, 11.

Kloosterman, P., \& Stage, F. K. (1992). Measuring Beliefs About Mathematical Problem Solving. School Science and Mathematics, 92(3), 109-115. https:// doi.org/10.1111/j.1949-8594.1992.tb12154.x

Linchevski, L., \& Livneh, D. (1999). Structure sense: The relationship between algebraic and numerical contexts. Educational Studies in Mathematics, 40(2), 173-196. https://doi.org/10.1023/ A:1003606308064

Metzuyanim, E. H., \& Tabach, M. (2017). The Commognitive Theory Framework: From Theory to Implementation. In K-12 Mathematics Education in Israel: Issues and Innovations (pp. 343-350).

Nardi, E., Ryve, A., Stadler, E., \& Viirman, O. (2014). Commognitive analyses of the learning and teaching of mathematics at university level: The case of discursive 
shifts in the study of Calculus. Research in Mathematics Education. https:// doi.org/10.1080/14794802.2014.918338

Naufal, M. A., Atan, N. A., Abdullah, A. H., \& Abu, M. S. (2017). Problem solving, based on metacommognitive learning activities, to improve Mathematical reasoning skills of students. Man in India, 97(12), 213-220.

Neufeldt, V., \& Guralnik, D. B. (1988). Webster's New World dictionary of American English. New York: Webster's New World.

Nunokawa, K. (2005). Mathematical problem solving and learning mathematics: What we expect students to obtain.Journal of Mathematical Behavior, 24(3-4), 325-340. https://doi.org/10.1016/j.jmathb.2005.09.002

Polya, G. (1954). Induction and analogy in mathematics. Princeton, New Jersey: Princeton University Press.

Posamentier, A. S., \& Krulik, S. (2009). Problem Solving inMathematics, Grade 3-6; Powerful Strategies to Deepen Understanding.Journal of Experimental Psychology: General (Vol. 136). California: Corwin.

Presmeg, N. (2016). Commognition as a lens for research. Educational Studies in Mathematics. https://doi.org/10.1007/s10649-015-9676-1

Pugalee, D. K. (2004). A Comparison Of Verbal And Written Descriptions Of Students' Problem Solving Processes. Educational Studies in Mathematics, 55, 27-47. https://doi.org/10.3201/eid0203.960317

Sáenz-Ludlow, A., \& Kadunz, G. (2016). Semiotics as a Tool for Learning Mathematics (How to Describe the Construction, Visualisation, and Communication of Mathematical Concepts).

Sangpom, W., Suthisung, N., Kongthip, Y., \& Inprasitha, M. (2016). Advanced Mathematical Thinking and Students' Mathematical Learning: Reflection from Students' Problem-Solving in Mathematics Classroom. Journal of Education and Learning, 5(3), 72. https:// doi.org/10.5539/jel.v5n3p72

Schoenfeld, A. H. (1992). Learning to think mathematically: Problem solving, metacognition and sense-making in mathematics. Handbook for Research on Mathematics Teaching and Learning. New York: MacMillan. https:// doi.org/10.1136/bmj.1.6053.66

Sfard, A. (2001). There is More to Discourse than Meets the Ears: Looking at Thinking as Communicating to Learn More About Mathematical Learning. Educational Studies in Mathematics, 13-57. https:/ / doi.org/10.1007/0-306-48085-9_1

Sfard, A. (2007). When the Rules of Discourse Change, but Nobody Tells You: Making Sense of Mathematics Learning From a Commognitive Standpoint. The Journal Of The Learning Sciences (Vol. 16).

Sfard, A. (2008). learning indoing: social,commognitive, and computational perspectives. Cambridge University Press.

Sfard, A. (2012). Introduction: Developing mathematical discourse-Some insights from communicational research. International Journal of Educational Research. https:// doi.org/10.1016/j.ijer.2011.12.013

Sfard, A., \& Kieran, C. (2001). Cognition as communication: Rethinking learning-bytalking through multi-faceted analysis of students' mathematical interactions. Mind, Culture, and Activity, 42-76. https://doi.org/10.1207/S15327884MCA0801_04

Sfard, A., \& Lavie, I. (2005). Why cannot children see as the same what grown-ups cannot see as different? - Early numerical thinking revisited. Cognition and Instruction, 23(2), 237-309. https://doi.org/10.1207/s1532690xci2302_3

Song, H. D., \& Grabowski, B. L. (2006). Stimulating intrinsic motivation for problem solving using goal-oriented contexts and peer group composition. Educational Technology Research and Development, 54(5), 445-466. https://doi.org/10.1007/s11423-006-0128-6 
Subanji. (2013). Teori Pembelajaran Kreatif dan Inovatif. Malang: UM Press.

Tabach, M., \& Nachlieli, T. (2016). Communicational perspectives on learning and teaching mathematics: prologue. Educational Studies in Mathematics. https://doi.org/10.1007/s10649-015-9638-7

Tasara, I. (2017). Commognitive analysis of a teacher's mathematical discourse on the derivative. Proceedings of the British Society for Research into Learning Mathematics (Vol. 37).

Thoma, A., \& Nardi, E. (2016). Routines in the didactical and mathematical discourses of closed-book examination tasks A commognitive analysis of closed-book examination tasks and lecturers' perspectives. Retrieved from https://hal.archives-ouvertes.fr/hal-01337904

Viirman, O. (2015). Explanation, motivation and question posing routines in university mathematics teachers' pedagogical discourse: a commognitive analysis. International Journal of Mathematical Education in Science and Technology. https://doi.org/10.1080/0020739X.2015.1034206 